\title{
Shades of Green Reporting: A Critical Discourse Analysis of Eco-News Reports in the Philippines
}

\author{
Philip Andrew L. Garlitos \\ palgarlitos@addu.edu.ph \\ English Cluster, Senior High School, Ateneo de Davao University, THE PHILIPPINES
}

\begin{abstract}
This paper uncovers the ideological representations found in the linguistic patterns of eco-news reports of national and local dailies in the Philippines. By bringing the 25 mainstream news reports on environmental concerns to analysis using Fairclough's (1992) Critical Discourse Analysis Framework and Halliday's (1985) Systemic Functional Linguistics, findings reveal that the news reports serve to promote different core ideas about destruction, allocation of blame, victimization, bias, risk and hazard, government's role, and objectification. Themes drawn out are found to represent nature as the enemy and the culprit of destruction, the government as the eco-warriors, the ordinary citizens as weak and defenceless versus the authorities as empowered and influential, and plants and animals as human commodities. By way of turning verbs into nouns, active to passive structure, and subject to its metonymic representation, human involvement is concealed as social actors are removed in the text construction. Despite maintaining the objective nature of news reporting, the discourse is produced based on the ideological standpoints of the writers, which may feed readers' understanding of the realities of nature and ecology as a whole.
\end{abstract}

Keywords: eco-news reporting, critical discourse analysis, linguistic patterns, ideological representations

\section{Introduction}

Over the past years, the Philippines has been on the headlines of various international newspapers. It is because of environmentrelated issues and phenomena. One of those that caught the world's attention is when Super Typhoon Yolanda (Haiyan), one of the strongest typhoons ever recorded, made landfall in Central Philippines. The world saw a massive impact through various media organizations, causing fears and worries for the families who were severely affected. It is an attestation of the Philippines being regarded as one of the countries highly vulnerable to environmental and climate-related challenges, with Maplecroft's Climate Change Vulnerability Index (2013) ranking the country as the $9^{\text {th }}$ facing the most extreme risks of climate change.
With the growing number of environmental concerns that the Philippines has been facing, communicating such matters, especially by media practitioners, cannot be dismissed from the investigation. Particularly, newspapers have played a significant role as a source of information in shaping public awareness and extending the knowledge about environmental affairs to the news consumers. Despite the emergence of new media platforms, the print media industry still shares a good portion of public consumption in the market. The power of the print media is still essentially recognized as it signals "what society and polity should be concerned about in setting the framework for definition and discussion of such issues" (Hansen, 2010, p.19).

Central to the production of news is the language. Language always plays a vital role in 
shaping social and political beliefs through the choice of words in newspaper articles. Language use has been the means that capacitates newspapers to represent sociocultural realities and exercise power to influence the readers. Humans, as language producers in the news discourse, have the sheer advantage of telling the stories within the scope of their human knowledge. The environment cannot speak for itself, including animate beings. Hence, the issue lies in how humans speak for and about the environment and whether the language serves the best interest of everyone or such that it advances the ideological position of humans.

It is therefore timely to subject the Philippine press coverage of environmental news to analysis since the direction of existing studies related to such kind of news has been that of mass or development communication. Additionally, the scope of the studied coverage was also at the height of environmental concerns in the country, when Super Typhoon Yolanda (Haiyan) passed through the central Philippine islands.

Guided by the Critical Discourse Analysis Framework of Fairclough (1992), this paper explores the salient patterns of language as seen through the lens of Systemic Functional Linguistics developed by Halliday (1985), to identify the core ideas that eventually advance the representations of the actors and participants in the eco-news discourse, and how they could affect the meaning construction for the news consumers.

Fairclough (1992), in his book Discourse and Social Change, regards language use as a form of 'social practice' rather than merely individual activity or a reflex of situational variables. Hence, language can never be analyzed in isolation, and that it should entail the condition of the context and society where it exists. This may imply two things: one is that discourse is a mode of action and a mode of representation, and the other is that there is a dialectical relationship between discourse and social structure, and social practice and social structure in general. Thus, Fairclough's model is called dialectical-relational, which focuses upon the social conflict in the Marxist tradition (Karl Marx as one theoretical attractor) and tries its linguistic materializations in discourse.

Fairclough's model draws upon M.A.K. Halliday's Systemic Functional Linguistic (SFL) as a linguistic means to analyze the social practices embedded in the text. SFL, as linguistic theory, views language in its 'social context', as an instrument of social interaction and not as an isolated formal cognitive system (Halliday, 1985). This theory emphasizes that every time the language is used, the language used makes 'choices'. These choices imbed social meanings and are realized through the semantic functions the language carries.

One of the semantic functions in SFL is the experiential function. Halliday (1985) explains that this function is about relating one's experience of the world. This bears on representations and recontextualizations of social practices that are achieved through the transitivity system (participants, processes, and circumstances). It asks: "Who does what to whom, when, where, and how?" The notion of transitivity enables the representation of extra-linguistic reality in multiple ways.

Central to the analysis of transitivity is the verb, which carries the representational experience of change in the clause. The analysis of action is the analysis of process types. Halliday and Matthiessen (2014) name six types of process: (1) material clause, the process of happening and doing; (2) mental clause, the process of sensing; (3) verbal clause, the process of saying; (4) relational clause, the process of being and having; (5) behavioral clause, the process of behaving; and (6) existential, the process of existing. The behavioral process was booted out from this study because aside from it not being a pattern in the news; it is also the least distinct among the process types because it has no clearly defined characteristics as it can be partly material and partly mental.

Actions cannot be accomplished without the agents and participants. By checking into agency and participation through nominal clauses, it can be drawn out "how agency and responsibility are represented through the use of different verb processes, particularly the negative social actions" (Richardson, 2007, p. 
225). Halliday and Matthiessen (2014) name these agents-participants as actor-goal for material clause, senser for mental clause, sayer-receiver for verbal clause, carrier and possessor-token for the relational clause, and the existents in existential clauses.

The properties of agents do not lodge only in their relation to the process represented. "The way that people are named in news discourse can have a significant impact on how they are viewed" (Richardson, 2007, p. 49). However, how social actors are identified does not imply only about their social characteristics and roles, but it can also signal the relationship between the named actor and the namer, in the case of news, the journalist. As cited in Richardson (2007), Blommaert (n.d.) explains:

Apart from referential meaning, acts of communication produce indexical meaning: social meaning, interpretative leads between what is said, and the social occasion in which it is being produced. Thus, the word 'sir' not only refers to a male individual, but it indexes a particular social status and the role relationships of deference and politeness entailed by this status. (p. 49)

These choices made in naming social agents have various purposes and objectives, such as psychological, political, and social intentions (Reisigl \& Wodak, 2001 in Richardson, 2007). Agents labelled as the father, ex-policeman, governor, fishermen, drunk, communist, or asylum seeker or by using a range of collectivized terms can be explicitly understood, but the context where such names are used may regulate how one must look at these references.

There are also grammatical devices that are used not only to serve linguistic purposes but more significantly to create specific effects (Merkl-Davies \& Koller, 2012), one of which is the effacement or obfuscation of agency. Salient in the news discourse are three devices that serve the said purpose. One is nominalization, which turns verbs and adjectives into nouns and allows the removal of details such as participants, time, or modality (Sušinskienè, 2009). Another device is metonymy, which, according to Jasinski (2001 in Richardson, 2007), is the "substitution in which something that is associated with X is substituted for X" (p.67). Zeliński (n.d.) explains that metonymy can come in different types, such as a product for producer or creator, object for the user, institution for people responsible, a place for an institution, place for entities living in the place, and date or place for the event. Lastly, by using passive voice instead of active, which is called passivization, it is possible to keep the agent in the semantic background and efface it in the surface structure of discourse.

There have been various yet contrasting definitions of eco-news as there are various and contending definitions of the environment. For one, Hasan (2007) settles with this definition: "Environmental news is defined in the broadest sense as all stories on environmental matters, not just issue-based coverage" (p.10). However, the term eco-news does not sit fixed only in Mother Nature; it includes stories about all living organisms and their interdependent relationship with their environment. Having said that, this study defines eco-news as any news story about the interactions among living organisms and their environment, also the events and issues that concern any of the wholes of them. It is grounded on the idea that living organisms such as animals, plants, and humans affect the environment where they live in the same way that the environment affects them as well. For clarity, this study uses eco-news and environment news interchangeably without any difference meant.

In the ranking report project principally written by Miller and Pollak (2012), it is explained why environmental coverage matters in America. One cited report shows that incorrect or outdated environmental myths heavily influence $80 \%$ of Americans. It conclusively links up the low level of knowledge and awareness about the environment and the unpreparedness for the possible environmental risks in the coming years. Some of these 'lacks' are manifested in the survey data which reveal that " $57 \%$ of Americans know the greenhouse effect, 50\% understand that most human activities cause global warming, $45 \%$ understand that carbon 
dioxide traps heat from the earth's surface, and $25 \%$ have ever heard of coral bleaching or ocean acidification" (p.8).

The extensive coverage and scope of econews must match with the level of journalistic expertise covering this particular area of journalism. Topics can go as far as the vast range of disasters, plants and animals, weather updates, conservation movements, legislation, environmental advocacy acts, and even degradation of natural resources.

Mass media's role in information dissemination is deemed vital when a natural disaster strikes such as typhoons. Based on the Annenberg Washington Program Report (in Li \& Rajaratnam, 2006), "the media have an obvious role when it comes to reporting news of natural and man-made disasters, and they also play an important part of effective preventive and rescue operations as well" (p.98). In the Philippines, disaster news stories have generated more news space and elicited more attention because of the longevity and intensity of the impacts.

Not as much as the coverage of disasters is the coverage of events and issues concerning animals and plants. News stories about them revolve around matters about their unique behavior, preservation; a festival celebrated after them, mysterious death, and even their captivity (for the animals). One famous example in the Philippines is the captivity of the then-largest saltwater crocodile in the world named Lolong. It became abuzz because of its unusual size and man's success in capturing such a huge crocodile.

Much has been rendered on reporting proenvironment movements such as coastal cleanup, tree-planting programs, protests against environment-threatening plans, environment advocacy campaigns, and the creation of environment-friendly projects. These news reports are usually about government-spearheaded activities.

Reports may also cover raids and sightings of illegal activities such as logging, quarrying, and mining. These reports frame how the government has been serious in the running after the people behind the environmental degradation operations happening in the remote areas. News on pollution and contamination, whether man-made or natural, often focuses only on what the government or expert has to say but not on any of the affected citizens.

\section{Methodology}

This study is qualitative employing Critical Discourse Analysis, specifically Fairclough's (1992) Framework, as this sought to analyze and discuss the patterns and strands of news discourse from a critical perspective.

There were 25 eco-news reports collected and used for analysis in this study. The corpora were from the published news articles in national broadsheets Manila Bulletin, Philippine Daily Inquirer, Philippine Star, and local broadsheets Mindanao Times, Mindanao Daily Mirror, and Sun Star Davao from November to December 2013. The collected news reports covered different environmental and ecological issues and events such as disasters, environmental degradation, conservation initiatives, plants and animals, weather updates, and environmental legislation.

An inductive approach was employed in studying discourse which was divided into two analytical levels: at the level of text, the system of transitivity, particularly agency and action, was examined using a systematic coding procedure; and the ideological representations promoted by textual patterns were identified and discussed.

Prolonged engagement with and persistent observation of the eco-news reports through coding procedure, analysis, and interpretation of the data was done to establish the validity and trustworthiness of this research. The results were presented systematically and discussed to conclude. These results were validated and reviewed by two experts in the field of discourse studies. 


\section{Findings and Discussion}

\section{Linguistic Structures}

The coding procedure was carried out to ascribe categories to the linguistic items found in the news reports. Hence, the emphasis of words and phrases in the cited excerpts is made to show the identified linguistic pattern/s, and the news writer did not originally make this. Through transitivity analysis, seven core ideas dawned through the linguistic patterns examined, and the traces of their representations were interpreted as critical discourse analysis is geared towards the analysis of language in context.

\section{Destruction}

One pattern that models the destructive nature of the disaster is the use of transformative verbs collectively called material processes. Material processes were noticed outright through the recurrent use of verbs that entail the sense of doing and happening, taking into account the actors responsible for these actions. Consider the example that follows.

'Vinta' Batters N. Luzon, 113 Families Evacuated

('Vinta' Batters N. Luzon, 113 Families Evacuated", Manila Bulletin, 2 November 2013)

The italicized verb presented implies the generation of energy to cause a transformative event or occurrence. Halliday and Matthiessen (2014) state that a material clause construes a quantity of change that comes about through some input of energy. Notably, the verb implicates a solid amount of force and energy, causing harmful and disruptive impacts, and evacuated compelling an immediate action to be done. The immensity of energy is evoked because disastrous events exceed normal protections (Kreps, 1984 in Lindell, 2011).

This pattern characterizing natural phenomena as a huge mighty force having unnatural physical power is related to the results of Trckova's (2012) study. After analyzing the metaphorical representation of natural catastrophes in newspaper discourse, it was found out that hurricane and tsunami as natural catastrophes are metaphorically described as a monster through the use of verbs like batter, smash, and ravage, which also imply violence of nature. She stated that such representation implies that natural phenomenon is more powerful than people.

The concept of forceful destruction during disastrous events is also manifested through examining the verbs that represent a relational process. The relational process concerns the representation of being and having. The value system of the writer paves the way for the construction of the idea of destruction. This pattern is realized by the use of auxiliaries and linking verbs. Take the following headline as an example.

\section{'Yolanda Was a Beast-CNN}

("Yolanda Was a Beast", Manila Bulletin, 9 November 2013)

The token, which is Super Typhoon Yolanda (Haiyan) is equated to a beast, connoting something large, impressive, difficult, and unpleasant to manage. This is so because Yolanda, as described in the article, 'generated storm surge up to seven meters high', 'packed winds of such velocity and terror that no instrument had been devised to measure it', and 'could possibly be the strongest typhoon in the world history', all implicate the atrocity of its cataclysmic strength.

It is also interesting to note how such disasters are named and referenced in the news discourse. Richardson (2007) contends that the way agents are named in the news affects significantly how they are viewed. Below is the sample.

Residents were caught by surprise as what they initially thought was approaching heavy rain suddenly formed into a huge violent rotating column of wind ripping roofs off houses.

("Tornado Wreaks Havoc in Cebu", Manila Bulletin, 6 November 2013)

The boldfaced expression above shows how the naming strategy applied by the writer addresses the destructive notion of a natural phenomenon. A wind tagged as a huge violent 
rotating column makes the ripping off the roofs of the houses believable and convincing.

Trckova (2012), in her study on metaphorical themes of natural catastrophes, discussed that the discursive devices used to represent hurricane and tsunami metaphorically provide a conceptual framework that portrays them as abnormal, angry, and monstrous. Similarly, in the present study, natural phenomena such as (super)typhoon, flash flood, tornado, and earthquake were modelled as cataclysmic and more powerful than humans, a social character that is capable of destroying man's control.

\section{Allocation of Blame}

The representation of how blame is allocated always follows when there is destruction. Through the linguistic patterns found, the traces of blaming were identified. Natural phenomena seem to be destructive, but they do not just occur without contributory causes. Hence, it is interesting to know who earn the blame on these calamities, and how they are ascribed in the course of econews reporting. The following excerpt serves as an example.

Malacañang, meanwhile, said Friday that President Benigno S. Aquino III is monitoring the situation of affected areas lashed by Vinta.

('Vinta' Batters N. Luzon, 113 Families Evacuated", Manila Bulletin, 2 November 2013)

In this example, the natural phenomenon is the identified actor responsible for the lashing, which is a negative social action in this context. The realization of this negative action is charged to the natural phenomenon, with people and the things that surround them as social victims. There seems to be no trace found linking the happening to the human contribution, and by depicting such a disastrous event as the social actor, it hides the fact that there are also social, economic, and political factors to take into consideration. The government, the private sector, and the society as a whole do not share in the blame for these events, which supports the findings of Trckova (2012) in the same study cited previously.
Humans in the language of eco-news reporting continue to have been distanced from the allocation of blame in terms of natural events through the example that follows.

He also pointed out that urbanization is another cause as the people themselves and construction projects cause the clogging of drainages.

("Climate change, urbanization at fault for recent flooding", Sun Star Davao, 5 November 2013)

The social process of urbanization is tagged as one of the culprits for the flooding. This passage was taken from the statement of a government official and was cited by the writer in an indirect quotation. Though people, along with construction projects, are named responsible for the flooding in the city, the use of nominalization hides the involvement of the government and the real estate developers who have a big contribution to these urbanization projects. The generalization of people and the substitution of construction projects instead of the people who construct these projects obviate the fact that the authorities and developers are part of the whole picture.

Another ideological linguistic strategy used in the allocation of blame is metonymy. Natural disasters could be attributed to natural phenomena, but some disasters are human-made. One example in the eco-news reports analyzed is the oil spill. News on human-made disasters such as oil spill also shows how the blaming game is materialized in the reports.

Damaged barge spills oil in Iloilo waters ("Damaged barge spills oil in Iloilo waters", Philippine Star, 13 November 2013)

The damaged barge is ascribed in this example, pinning the responsibility of agency on it. Here, the barge is a creation of a human, a property of National Power Company (Napocor). It needs fuel to function and people to operate and maintain the operations. However, in this November 13, 2013, Philippine Star headline, it seems to hide the human involvement, even though the event 
happened by accident. It takes away the fact that the barge was placed in the area because of human efforts, as well as the filling of the oil it contained. When it spilled oil in Iloilo waters, the people who stationed the barge there and filled it with oil were void of the blame.

\section{Victimization}

After identifying how the linguistic patterns construe the allocation of blame, it necessarily follows how the idea of victimization is represented as well. Material clauses were identified to check up on the goals that are affected by the actions brought by the actors. Note how this is demonstrated in the selection that follows.

In Cebu, at least $\mathbf{3 5}$ houses were damaged and nine persons suffered injuries in Mandaue City, Lapu-Lapu City and Compostela town.

("Tornadoes wreak havoc in Cebu, Iloilo areas", Philippine Daily Inquirer, 7 November 2013)

The passage shows that the ones affected by the destruction are the 35 houses and further states that nine persons suffered injuries (though a mental clause). Literally, houses get damaged or destroyed during calamities, but digging more into it, it is the people who live in these houses, and even if they do not incur any injuries, they are still highly affected and made victims for losing their properties.

Using intransitive verbs can also hide the perpetrator of wrongdoing, as such is exemplified in victimizing animals.

Wounded eagle found in North Cotabato dies

("Wounded eagle found in North Cotabato dies", Mindanao Times, 2 December 2013)

The use of dies removes the inclusion of a perpetrator, as the verb is intransitive. The passage above is a headline, and headlines, as Iarovici and Amel (1989, as cited in Richardson, 2007) put it, "alert the reader to the nature or the content of the text" (p.197). This means that as the headline suggests it, the article foregrounds the death of the eagle and not who shot the eagle, especially that the identity of the perpetrator was still unknown. The article even mentions unattributed related information on the death of another male Philippine eagle, which reads, 'a male Philippine eagle was killed in Misamis Oriental'. Even though the writer chooses a transitive verb to describe the social action, the agent remains obscure in the statement because of the passive construction that enables the doer of the action to be removed from the clause.

Metonymies are also manifested in modelling the victims, especially during disasters. Common are metonymic places replacing the entities that dwell in them. The following is an example.

Basey residents believe they were hit by a tsunami rather than a storm surge, which devastated Tacloban City...

("Tsunami, not storm surge in Samar town?", Philippine Star, 16 November 2013)

The destruction caused during Yolanda's strike was deemed huge, that it would be suitable to use Tacloban City than individualizing the entities affected in it to save space. In the language of disaster and even weather reporting, names of places such as cities, provinces, and even countries are ascribed to certain phenomena. This geographical attribution bears on the nature of the calamities such as aerial for typhoons, land for quakes, and aquatic for tsunamis, among others. Hence, the geographical locations of the affected areas represent the scope and range of the impact of calamities.

\section{Bias}

Social biases are also present in eco-news reporting achieved through naming and referential strategies. As much as the writers try to do away with being inequitable, the patterns of naming and reference disclose the titles and affiliations of the people who hold power and depersonalize. It also generalizes those who do not. People are referenced according to their social and political statuses, which impress their influence among the readers. 
It is common in news discourse how government officials are named through their positions, professionals through their titles, and how locals and 'ordinary' people are individualized and collectivized, introduced as 'some', a '30-year-old', or as a 'fisherman'. Reisigl and Wodak (2001 in Richardson, 2007) assert that these naming and referential strategies realize various psychological, social, or political intentions on the part of the news writer. These intentions may further some ideological assumptions implicit in the discourse.

Councilor Mansueto Delovino, a former mayor of Basey, said many others told similar stories of the apparent tsunami.

("Tsunami, not storm surge in Samar town?", Philippine Star, 16 November 2013)

One bias in eco-news reporting is on referring to the previous position of an official. Delovino, one of the current councilors of Basey, is referred to as the former mayor of the town, authorizing the statement he made in the article. The writer believes that the ascription of title and a former title of a cited source makes him or her appear reliable to the readers. This is true with news writing, especially when a direct or indirect quotation is introduced.

The bias in naming people in news reports was examined by Alo and Ongungbe (2010) in their study Lexicalization in News Stories of Some Nigerian National Newspapers. They resolved that biased naming choice of the reporter is an attempt to control the reader trickily. They even continued that the sensationalized naming in Nigerian newspapers can uncover ideological assumptions. Hence, this study would also relate the biases in naming people to social inequalities embedded in the language of the reporter.

\section{Risks and Hazards}

Eco-news reporting also hovers around risks and hazards as a core idea. Representing this core idea is actualized by verbal processes such as warning, alerting, and advising and naming and referential strategies to refer to the weather disturbances, damaged infrastructures, and contamination, among others. Take this weather news as an example.

Fishermen warned vs. monsoon surge

("Fishermen warned vs. monsoon surge", Philippine Star, 25 November 2013)

In terms of weather forecasts, the verbal process or the process of saying is used more than any other process. This is since forecasts are verbally stated as weather forecasters provide updates and warnings on the effect of different atmospheric conditions. Hence, the boldfaced verb warned relays the risks and hazards the weather changes might bring, having been foreseen by the experts, specifically the people in PAGASA, the Philippine weather bureau. Of course, such is not just a sort of friendly reminder, but it is an order that must be heeded.

He said residents must be wary of tension cracks, especially those that are visibly leaking and the possible direction of the soil erosion.

("MGB 11 to Mt. Diwalwal residents: Be vigilant", Sun Star Davao, 26 November 2013)

In the context of this passage, the indirect quotation was taken from the words of Allen Buenavista, a geologist who spoke during the Makigsayud Forum with the indigenous peoples regarding the latter's living conditions in Mt. Diwalwal. The reporter chose to be in a neutral position in endorsing the statement by the use of said interestingly because it is an expert voice. Hasan (2007), who studied the representation of environmental news between two newspapers, asserted that environmental news reporters had found difficulty in presenting the scientists' voices because of the latter's expectations that the information must be written as complete as it is in science journals. Hence, terms like tension cracks and soil erosion could not seemingly be put differently to help readers who find the terms novel to them come across the meanings conveyed in the report. 


\section{Government's Role}

The representation of the role of the government in eco-news reporting perceptibly dawned on the patterns analyzed. This representation focuses much on its implementation of pro-environment actions, giving orders and directions, and strengthening environmental legislation through different linguistic patterns. Substantiating these patterns unfolds the ideological construction of the government's image in the eco-news reports. Consider the one that follows.

The Bureau of Fisheries and Aquatic Resources (BFAR) 11 is eyeing the development and promotion of organic aquaculture in the Davao Region to give Dabawenyos healthier food choices.

("Agriculture now going organic", Mindanao Daily Mirror, 15 December 2013)

The passage helps figure how serious the government is in executing concrete actions towards positive social and environmental changes. In the event of a positive process (eyeing), the foregrounded agent is the government. BFAR is given the emphasis on considering the idea of practising organic aquaculture in Davao Region, which yields to an end of promoting the welfare of the people. This goes to show that the government looks after the safety of its people by finding ways on how to ensure their conditions and does not stop in coming up with better ideas.

Observably, the different government entities cited are metonymically represented as an institution, as a project, or as a government department instead of individualized agents. Consider the example that follows.

Over-all, the NGP program of the DENR to date has already planted thousands of tree seedlings at various areas in the 6 cities and 5 provinces in the Caraga region.

("Greening Program in Caraga Region", Manila Bulletin, 21 December 2013)

As highlighted, the writer of the eco-news metonymically represents the actor by writing
NGP (National Greening Program) instead of the tree planters. Zeliński (n.d.) provides a proposition that in the political context, "metonymy is used as a tool for glorification, or vilification of certain entities (people, countries, organizations, etc.), and when not used by politicians themselves, journalists tend to favor it in articles" (p.11). In the core idea of governance, these metonymies are used in extolling the good works of the government. By collectivizing them, it means that the whole institution or government department is actively at work.

The use of metonymy for institution, organization, or country was detected in the analysis of headlines in newspaper editorials by Bonyadi and Samuel (2013). Editorial writers in their examples intended to refer to a Chinese company, Russian leaders, political status in Lebanon, and the Chinese government, respectively. By imposing their attitudes, the writers used metonymy to generalize the issues.

\section{Objectification}

The idea of objectifying 'other' creatures emerged in the eco-news discourse. Plants and animals do not write themselves news concerning them; humans write them. It was made possible through the relational process and naming and reference.

Desamparado...believes the mangroves growing on many parts of the islet are buffers against the wind and waves.

("Mangroves shielded Sagay islet's residents", Philippine Daily Inquirer, 29 November 2013)

In this passage, the mangroves are equated to buffers as they reportedly shielded the residents from the storm surge generated during the super typhoon. Mangroves are types of trees and shrubs that grow in the wetlands and are known to prevent soil erosion and slow down the flow of water. They are buffers, as the quoted resident stated, which suggests their significant function during coastal calamities. This statement implicitly shows an objectification of the mangroves, saying that they are valuable to humans, but as commodities, they can count on 
when they are in trouble. It captures the anthropocentric treatment of the plants because they are seen to exist for the benefit of humans. It even continues in this article that islets must grow mangroves because they help mitigate the gravity of a typhoon'. They are deemed important when they are in use, but once they are destroyed, humans can just easily replace them by planting new mangroves. The Los Baños-based DENR Ecosystems Research and Development Bureau cited in the December 2, 2013 issue of Philippine Star titled "Disasters blamed for dwindling Phl mangrove forests" (which is also ideological in terms of allocation of blame) even said that 'mangroves serve as breeding, feeding and nursery grounds for fish and crustaceans' and thus must not be destroyed. On the one hand, this can be positively ideological for highlighting that mangroves are of natural importance among marine animals. On the other hand, this can evoke an idea that mangroves must be preserved so that fish and crustaceans multiply (breeding, feeding, and nursery), which means more catch for the fishermen, feeding the human-centred view of things and the objectification of mangroves.

Another angle to consider in probing how plants and animals were represented in the news discourse is how they are named and referenced. The choice of using adjectives and other modifiers can also show how objectification is manifested.

\footnotetext{
"It seems that our Butandings have returned," but that they have changed their schedules," he added.

("'Butanding's Return to Donsol", Manila Bulletin, 8 December 2013)
}

Plants and animals do not name themselves, and thus their names and titles are human-influenced. Notice how the Butandings or whale sharks are personalized by the use of possessive pronoun our, referring to their return to Donsol. It can be contested that the writer could have used the Butandings to establish an exclusive identity of the whale sharks, but the choice of personalizing them corresponds to the idea of 'owning' them. It suggests an objectification of whale sharks as Donsol's properties. This is even supported by the article's headline which reads "Butanding's
Return to Donsol" that foregrounds the 'return', the phenomenon where Donsol residents especially the ones whose living is tied to whale shark sightings can benefit much from, instead of "Butanding Returns to Donsol", foregrounding the whale sharks. It must be seen as something that advances an ideological framing of news.

\section{Ideological Representations}

The ideological representations were unravelled by looking into the core ideas promoted by linguistic patterns found in the eco-news discourse.

\section{On Nature}

The nature of depicting natural phenomena has been portrayed as having extraordinary attributes, particularly ruinous and frantic, as if with emotions. However, humans still have found their edge over nature-that is, nature cannot speak for itself, cannot write for itself, and, most of all, cannot defend itself. It is then through language that humans regain power through blaming and slandering nature's calamitous tendencies and claim their innocence in the realm of creation.

At least 13 persons were injured while 20 houses were damaged when strong winds toppled trees and lifted house roofs in areas in Mandaue and Lapu-Lapu cities... ("Tornado Wreaks Havoc in Cebu", Manila Bulletin, 6 November 2013)

Last week at the height of the monster howler Yolanda, the heavy rain suddenly stopped, and the wind died down in this fishing town facing the Pacific Ocean.

("Tsunami, not storm surge in Samar town?", Philippine Star, 16 November 2013)

"The Philippines may have fallen victim this early, but we will all eventually become victims of climate change."

("Walkout Mars UN Climate Talks", Manila Bulletin, 22 November 2013)

Disasters blamed for dwindling $\mathrm{Phl}$ mangrove forests 
("Disasters blamed for dwindling Phl mangrove forests", Philippine Star, 2 December 2013)

The identified linguistic patterns serve to promote the representation of nature as an enemy. Through the material process, strong winds have been attributed to the capacity to topple trees and lift house roofs, illustrating clearly the intensity and power they possess. Super Typhoon Yolanda has been named as monster howler, while climate change has been accused of having victimized the Philippine nation. The passive structure holds the disasters responsible for destroying mangroves and further anonymizes the identity of who made the blame.

These ideological representations of nature draw on the Enlightenment ideology of the superiority of man over nature found in the study of Trčkova (2011) on metaphorical representations of natural catastrophes in newspapers. She asserted that the aftermath of the catastrophes took away man's control of reality, and so the newspaper discourse drew back from rational thinking and resorted to mythical thinking-that is, by demonizing nature. Though the newspaper put nature at the pinnacle of creation, having all the power over humankind through its destructive characteristics, humans still found a way to regain dominance. Power over nature was invested by pinning all the blame on nature and thus hiding the fact that the calamities were also a result of human contribution and failure.

\section{On Flora and Fauna}

Part of the domain of creation is the kingdom of species. Plants (flora) and animals (fauna) are also ideologically represented because, like nature, they cannot write for themselves and further their ideologies about and against people. Hence, a biased representation of flora and fauna continues to be patent through linguistic patterns.

The almost forgotten casualties of Supertyphoon "Yolanda" are the farm animals that happen to be major sources of livelihood of most survivors in stormbattered Leyte province.
("Animals key but forgotten in storm relief work", Philippine Daily Inquirer, 12 December 2013)

"We are looking at a next big attraction," said Oliva of the MFR, which he likened to a "sleeping giant" because of its big potential to draw not only scientists and researchers but tourists and hikers as well. ("Makiling: Ecotourism's 'sleeping giant'", Philippine Daily Inquirer, 21 November 2013)

The objectification of plants and animals has been advanced by the use of the relational process and naming and reference. The first passage, although provokes a concerned tone about the animals, is linked to the idea that saving them during the storm would also mean saving the people's major livelihood, which is livestock farming. The significance of farm animals is not drawn from their being animals having the life and right to it but from their purpose in serving man's interests. In the second passage, naming Makiling as a sleeping giant and big potential sees the forest reserve as a hugely important property that can be used for research and tourist visits, again by humans. It suggests that man can determine how much worth the forest possesses in terms of its usability for man's gain, for the goods and services it can offer.

The ideology of anthropocentrism corresponds to the nature-culture dualism of the representations of nature. While both of these affect environmental ethics, their enclosure in the eco-news means one thingto sustain the domination and power of humans in the hierarchy of creation.

\section{On Society}

Power relations in the eco-news discourse are not fixated only on human-nature, humananimal, and human-plant dualisms. The econews reporting by the mainstream newspapers has also portrayed the different social players of different social classes ideologically. CDA, as a critical framework to discourse analysis, aims to examine whether a discourse such as reporting relates to or reflects wider structural and social inequalities (Richardson, 2007). It can be 
addressed through the representations of social actors.

Naming the locals and those who are in the higher class has shown explicit differences that imply biases. Locals are generalized, while elites are specified. When both are specified, social statuses get to be attributed to the titles that come with their names. Notice the examples that follow.

In just a couple of minutes, affected residents said the water level at the Davao Gulf suddenly rose waist-deep in Branagays Aplaya, Ruparan, and Cogon following moderate but continuous rainfall.

("Flash Floods Sweep Digos City", Manila Bulletin, 16 November 2013)

"It was such a beautiful sight starting around 5 p.m. when they would all fly together, thousands of them...", recalled Marife Matugas, 40, a laundrywoman with four children.

("Destruction of giant bat sanctuary a great loss for Palompon-envi exec", Mindanao Daily Mirror, 2 December 2013)

Police Supt. Romy Palgue, deputy director of the Butuan City Police Office, said an anonymous informant told the Presidential Anti-organized Crime Commission (PAOCC) about the presence of the logs in barangay Mahogany.

("P6.9M worth of illegal logs seized in Butuan", Mindanao Times, 1 December 2013)

Zeta's daughter Hazel Zeta-Dy Tioco, a multinational pharmaceutical executive, is one of the Basey natives living in Manila who are lobbying for aid to be immediately sent to the town....

("Tsunami, not storm surge in Samar town?", Philippine Star, 16 November 2013)

The first two passages demonstrate how locals are named in the discourse: they are either generalized as residents or specified as naming Marife as a laundrywoman with four children, whose writer may have the choice to mention Marife by her name alone. On the other hand, the elites are named with their titles attached to them, lending credibility to their accounts and roles in the news stories. In the case of Hazel Zeta-Dy Tioco, she has been referred as the daughter of a politician, aside from her being an executive, making her a 'credible' personality to lobby for aid and disaster response. Such naming strategies demonstrate the choices made by the news writers since these people do not necessarily suggest how they are to be named in the news articles.

The precedence of elite sources in news media was confirmed in the survey conducted by Pompper (2004 in Cox, 2013) on covering environmental risk stories by three (3) U.S. newspapers. She found out that the elites and non-elites have different frames of risks-the elites see risks in terms of official assessments and safety assurances, while non-elites talked about their concerns about dangers, not to mention the dominion of elite voices drowning out the non-elite. This clearly shows that elites are represented as thinkers, careful observers, and opinion formulators and credible at these.

\section{On Government}

In almost all the eco-news articles, the government is represented and heard. From the local government units and servicing departments to national offices and heads, the government has been spotlighted. According to Buttry (2011), in his online article, "You can quote me on that: Advice on attribution for journalists," attributing sources is the key element in the news story's credibility. By relying too much on the authorities, it creates a picture of them that is credible in terms of concerns and issues about the environment.

Task Force Taal had demolished a total of 7,943 fish cages in the volcanic lake and 280 others at the Pansipit River, the only tributary that connects the lake to Batlayan Bay, the governor added.

('Protect Sea, Underwater'", Manila Bulletin, 5 December 2013)

"Do not get any illegal forest products from anyone. Do not let us run after you because we are really resolute in implementing E.O. 23 by all means," he told the dealers. 
("Getting creative: 'Hot logs' transported in passenger vehicles", Mindanao Times, 15 November 2013)

To conserve on communication materials and preserve the environment, the Municipal Council here affirmed that it will carry out the original plan of a "paperless session" in its succeeding meetings.

("Paperless Sessions", Manila Bulletin, 5 December 2013)

All these passages affirm the role of the government in the eco-news discourse: they are the eco-warriors. By attributing positive processes such as demolishing fish cages, legislating ban against illegal logging, and carrying out paperless sessions to save trees, the government has been a protagonist in the environmental narratives plagued by problems and issues.

The representation of the government as an eco-warrior is an example of propaganda. This ideology draws on the general theory of the free press of Herman and Chomsky (1988 in Mullen \& Klaehn, 2010) which emphasizes "that the Propaganda Model presents a 'free market analysis' of mainstream media, 'with the results largely the outcome of the working of market forces'” (p.217). The Propaganda Model challenges the 'notion' that mainstream news is committed to public interests by serving balanced public news. It nonetheless suggests that the structural contexts where news is produced are that the news media tends to suffice propaganda schemes 'within capitalist, liberal-democratic societies.'

\section{On Underrepresentation}

The texts are not only about representations of different social players of environmental news, but traces of underrepresentation must also be noted. All the ideological representations are concerned about the presence of social agents and how they are portrayed in the texts, but the absence of these social agents also has ideological implications. These absences are achieved through linguistic patterns such as nominalization, metonymy, and passivization to hide the agents responsible for social actions, especially those that are incriminatory and so to hide ideologically embarrassing and uncomfortable assumptions. Consider these examples.

Climate change and urbanization were pointed as culprits for the flooding that hit nine barangays in Davao City last October 31 said an official of the city's Drainage Maintenance Unit (DMU).

("Climate change, urbanization at fault for recent flooding", Sun Star Davao, 5 November 2013)

The province's rich resources are currently threatened by a plan to construct a coalfired power plant in Aborlan.

("WWF urges use of clean, renewable energy in Palawan", Philippine Star, 17 November 2013)

In October, a male Philippine eagle was killed in Misamis Oriental, barely two months after it was released back into the wild-and after two years of rehabilitation.

("Wounded eagle found in North Cotabato dies", Mindanao Times, 2 December 2013)

The first excerpt has worked out to evade social agency and responsibility for the negative social actions committed. Urbanization is tagged as the culprit for the flooding in the city. By transforming the word into a noun, it makes it possible to hide who acts upon this urbanization.

In the second excerpt, the use of metonymy is also a demonstration of manipulation. The agents who are responsible for threatening the rich natural resources of Palawan are obfuscated through using the mental product plan instead of the producers of this plan to construct a coal-fired power plant.

Such is the same with the death of a Philippine eagle. The one who killed the eagle by way of shooting it is removed from the narrative. However, the agent supposedly charged to the eagle's release is also hidden, perhaps to avoid passing the incrimination to him or her, who is potentially a government official. These are achieved through 
passivization, which can hide the doer of the action and highlight only the receiver.

This ideological strategy corresponds to the findings of the contrastive study of Yaghoobi (2009) on the representations of the Hizbullah-Israel war by print media. It was found out through transitivity analysis that there were patterns of mystification of the agency found by way of checking into the passivization and nominalization in the news texts. The print media could have involved the Israeli soldiers explicitly and be made responsible for the attacks had it not transformed the assaulting verbs into nouns. On the other hand, Kayhan International utilized passive construction to make the actions of Israel more salient than the actions of Hizbullah guerrillas. Yaghoobi concludes that through critical discourse analysis, the choices that manifest the manipulation of the writer and the representation of ideologically produced meanings not always explicit for the readers were revealed.

\section{Conclusion}

The results and discussion clearly show how green reporting has accommodated linguistic patterns that implicitly and explicitly serve to promote ideological assumptions of discourse producers. They illustrate how the writers' choice-making has been plagued with biases since they decide what to include and exclude in the news discourse. Further, looking into the ideologies in the eco-news makes one ask how such ideological constructions have been fed into and produced from the consciousness of the news writers, not to mention the mainstream journalistic aim at remaining objective and neutral. The question is not about whether journalists may be consciously or unconsciously aware of their productions and reproductions of ideological assumptions but on how and why such ideologies are put into their conscious thinking. This can be addressed by looking at the bigger picture-the editors' and news company's influence, personal influence, and the dominant ideology's influence.

People live with preconceived notions, and these notions continue to change and be shaped through experiences and more exposure to social constructions of reality through daily discourses. Journalists do not write only from what they see, hear, and know, but they also write with the influence of their belief system and eventually extend this to the public sphere. Language in context constitutes power relations in the society, and such sustenance of power and domination affects how social reality is understood. This study proved how human language could exercise its capacity to construct perceptions about the environment and society in general, that beneath the so-called one color of discourse lie the many colors of social realities.

\section{References}

Alo, M. \& Ogungbe, E.O. (2010). Lexicalization in news stories of some Nigerian national newspapers. Lumina, 23, 2, ISSN 2094118.

Buttry, S. (2011). You can quote me on that: Advice on attribution for journalists. Retrieved from https://bit.ly/2NKFcge

Bonyadi, A. \& Samuel, M. (2013). Headlines in newspaper editorials: A contrastive study. Retrieved from http://sgo.sagepub.com/ content/3/2/2158244013494863

Cox, R. (2013). Environmental communication ( $3^{\text {rd }}$ ed). Thousand Oaks, California: Sage.

Fairclough, N. (1992). Discourse and social change. Cambridge: Polity Press.

Halliday, M.A.K. (1985). An introduction to functional grammar. London: Edward Arnold.

Halliday, M.A.K. \& Matthiessen C.M.I.M. (2014). Halliday's introduction to functional grammar. Oxford: Routledge.

Hansen, A. (2010). Environment, media, and communication. Oxon, UK: Routledge.

Hasan, N. (2007). The Representation of environmental news: A comparative study of the Malaysian and New Zealand press [PDF File].

Li, L.M. \& Rajaratnam, U.D. (2006). Waves of destruction: A portrayal of a natural 
disaster by the mass media. Jurnal Komunikasi: Malaysian Journal of Communication, 22.

Lindell, M.K. (2011). Disaster studies. Sociopedia.isa. Retrieved from http://www.sagepub.net/isa/resources/ pdf/Disaster\%20Studies.pdf

Maplecroft's Climate Change Vulnerability Index. (2013). Maplecroft Global Risk Analytics. Retrieved from

https://bit.ly/2X8IVHe

Merkl-Davies, D. \& Koller, V. (2012). 'Metaphorising' people out of this world: A critical discourse analysis of a chairman's statement of a UK defence firm. Accounting Forum, 36, 178-193.

Miller, T. \& Pollak, T. (2012). Environmental coverage in the mainstream news: We need more. SEE Innovation.

Mullen, A. \& Klaehn, J. (2010). The HermanChomsky propaganda model: A critical approach to analyzing mass media behavior. Sociology Compass, 4(4), 215229.

Richardson, J. (2007). Analyzing newspapers: An approach from critical discourse analysis. New York: Palgrave Macmillan.

Sušinskienè, S. (2010). Nominalization as a cohesive device in British newspaper editorials. Filologija, 15, 142-150.

Trčková, D. (2012). Metaphorical representation of a natural phenomenon in newspapers discourse on natural catastrophes. Journal of Critical Approaches to Discourse Analysis across Disciplines, 5(2), 137-151.

Trčková, D. (2011). Representation of natural catastrophes in newspaper discourse: Portrayal of human-nature relationship. Unpublished doctoral dissertation, Masaryk University. Retrieved from http://is.muni.cz/th/63689/ff_d/PhDthe sis.txt

Yaghoobi, M. (2009). A critical discourse analysis of the selected Iranian and American printed media on therepresentations of Hizbullah-Israel war. Journal of Intercultural Communication, (21). Retrieved from http://www.immi.se/intercultural/nr21 /yaghoobi.htm

Zeliński, P. (n.d.). Metaphors and metonymy in politics. Selected aspects. Retrieved from http://www.omniglot.com/language/arti cles/metaphorsinpolitics.htm 